\title{
Editorial: An Introduction to the Journal
}

The vast majority of published literature on Islam and ethics approaches these topics in an abstract and philosophical manner, rather than practically explaining how Muslims can implement their faith's ethical principles in their own lives. This has led to a disconnect between what Islam asks of its followers and their actual ethical practices. Practicing Islam as it was intended to be practiced requires a heightened level of ethics and should be embedded into the practice.

The changes in societies across the globe, which began during the twentieth century and continue today, have been more significant than at any other period in the history of the Muslim ummah. We are living in a very complex and confusing time. While humanity is making enormous strides in technology and science, making the world smaller and more accessible, we are seeing increasing levels of loneliness, anxiety, and depression among people. In the age of social media where people are "connecting" on multiple platforms, the question is: Why do they feel so disconnected from each other and the world?

According to the Substance Abuse and Mental Health Services Administration, each year about 42.5 million American adults (or 18.2 percent of the total adult population) suffer from some mental illness, enduring conditions such as depression, bipolar disorder, or schizophrenia. In 2016, the Centers for Disease Control and Prevention stated that suicide was the tenth leading cause of death overall in the United States, claiming the lives of nearly 45,000 people. Technological change is transforming how we understand the human body.

While health and disease are being reconsidered, recent advances in genetic engineering and biotechnology are becoming commonplace and affecting our core beliefs about humanity. Questions related to women, gender, family structure, race, and ethnicity have all affected the character and range of applications in society. While advancing in astronomy, astrophysics, and environmental science, scientists continue to discover and emphasize the human impact on creating global environmental problems. This is raising complex ethical, moral, social, and legal questions with which Muslim scholars and communities are struggling. Despite the scholars' efforts to develop competing conceptual and methodological approaches that can successfully engage societal change, the challenges remain significant and the proposed solutions remain limited.

The challenge is not to formulate rules or provide definitive, unproblematic answers; rather, it is to cultivate a knowledge ethos and reconstruct identities that can foster the ability to undertake and engage in creative and critical thinking as well as develop one's ethical problem-solving abilities. As such, this issue of the journal seeks to instigate further discussions and analyses concerning the ethical 
questions that our intellectuals, activists, practitioners, and researchers from other fields of knowledge should be asking and trying to answer. Those involved in such discussions also need to raise the difficult issue of how to formulate these critical questions in terms that are familiar to everyone.

Islam's responsibility-based system of ethics invokes reciprocal rights and duties. Thus, a range of social actors - parents, teachers, professionals, all individuals, including you - need to become active moral agents.

The Qur'an is the primary source of guidance, as it lays down a unified ethical system anchored in eternally valid and life-enriching moral principles and rules. The Prophetic Sunna represents and applied the ethics, morals, and behaviors outlined in the Qur'an at the highest possible level, as practiced by the Prophet (pbuh). Therefore, the ethical discourses are part of the Qur'an's teachings, the prophetic traditions, juridical literature, theology, mysticism, philosophy, and literature - in short, all of the major disciplines of Islamic thought.

In this issue, we highlight some of the challenges and issues faced by Muslims who want to implement Islamic ethics in their own lives. Muslims in the United States are experiencing a crisis of identity and confusion about their faith's principles and practices. We explore some of these and suggest how we can ameliorate this complex reality by finding ways to make our tradition more coherent and understandable. This approach recognizes the importance of holding relevant dialogues among academics, researchers, religious scholars, practitioners, and those working on the ground. Moreover, we continue to search for a more comprehensive methodology of applied Islamic ethics that remains faithful to Islam's fundamental principles, considers our contemporary context, and allows those who adopt it to remain faithful to their Islamic principles while actively participating in and contributing to their societies. The Journal of Islamic Faith and Practice will continue this dialogue in order to build our knowledge and expand our experiences on how to address contemporary challenges in the most realistic manner.

This collective effort sets forth the relationship between Islamic ethics and law, clearly revealing the complexity and richness of the Islamic tradition as well as its responsiveness to these controversial modern issues. The contributors analyze classical sources and survey the modern ethical landscape to identify guiding principles within Islamic ethical thought. Clarifying the importance of pragmatism in Islamic decision-making, they also offer case studies related to specialized topics.

In her "Towards a Muslim Ethics of Care: Leadership in American Islamic Schools," Amaarah DeCuir uses her analysis of qualitative interviews of Muslim women leading American Islamic schools to advance the concept of a Muslim ethics of care that communicates the caring work of school leaders rooted in establishing equity. Her conceptual framework is based on four themes: (a) caring 
to lead with equitable school practices, (b) caring as resistance to oppression, (c) caring through nurturing often described as "other mothering," (d) and caring as an Islamic obligation. By placing their voices within the broader context of a critical ethics of care framework, she demonstrates the role of faith-marginalized community leaders as social justice advocates.

In her "Walking Gently on the Earth": An Interview with Nana Firman on Islamic Environmental Ethics," Daniel Hummel, Ph.D., and Mohamed Daassa explore the relatively new field of Islamic eco-theology, defined as realizing the importance of protecting the environment and living a "green" lifestyle. The focus in placed on an interview with environmental activist Nana Firman, director of GreenFaith and the co-director of the Islamic Society of North America's Green Mosque Initiative.

Perhaps the most important take-away of this article in the following quote:

The word āyāt in Arabic means "signs" which are used to describe the verses in the Qur'an. But it can also be used to describe the evidence for our Creator in the environment. Can you imagine if one $\bar{a} y \bar{a} t$ is taken away from the Qur'an? How would the Muslims react about that? But why don't we feel the same when a species goes extinct? That is one ayah for the sign of God which has been erased from the planet because of our behavior. Where is the outrage for this? Those are equal to me.

In their "Navigating Ethical Dilemmas Between Professional Mental Health Ethics and Religious Values," Khalid Elzamzamy and Hooman Keshavarzi discuss the numerous issues that religiously committed Muslim mental health practitioners face when their perceived or actual religious mandates are at odds with their client's values and the mandates of their professional ethical codes of conduct. Examples of such conflicts are dealing with abortion, sexual orientation, gender identity, consensual extramarital affairs, substance and alcohol use, and nominal Muslims - all of which can have serious legal consequences. Refusing to treat such clients or tying to transfer them to other mental health practitioners can also have serious legal consequences. The authors present several strategies to reconcile these potential conflicts, such as bracketing their own views, using certain tools to manage such conflicts, or constructing Islamic ethical codes of conduct that review, integrate, and adapt current professional ethical standards to make them more consistent with a theistic ethical framework of practice.

In her article "Practicing Clinical Bioethics: Reflections from the Bedside," Asma Mobin-Uddin argues that in relation to the American Muslim context, "One thing is clear: What is happening on the ground today is not meeting the desperate need of patients, families, and medical personnel in addressing the ethical dilemmas common in medicine today." 
Bioethics, a relatively new discipline that began in the 1960 s, focuses on how to "apply moral philosophy and ethical principles to medical dilemmas." Given the increasing number of observant Muslims now living in the United States, this raises important questions among all stakeholders, such as what do the Islamic sources have to say about pursuing modern medical treatments that were unknown to classical-era Muslim medical specialists, how does one become qualified to make decisions about these treatments, and to whom can the parties involved turn for accurate advice when such cases arise?

In an attempt to resolve similar questions about medical dilemmas in the greater community, the position of "clinical ethics consultant" emerged during the 1980s. With regards to the American Muslim experience, the resources and guidance offering Islamic support in medical decision-making have been limited. Mobin-Uddin cites several case studies involving Muslim patients acting on advice they received from Muslim sources that could have been handled differently, had the patients and family members known that there were other religiously sanctioned options available. Although some work in Islamic bioethics scholarship is being done, apparently it is not reaching those who need it the most: Muslim patients and families as well as Muslim medical professionals currently engaged in clinical work. She concludes her article by declaring that this reality must be fixed now, not at some indefinite date in the future.

In her "Transformational Teaching: Prophet Muhammad (peace be upon him) as a Teacher and Murabbī", Zainab Alwani argues that the Prophet's (peace be upon him) role as a murabbi - a broad term that encompasses the roles of teaching, mentoring, advising, and guiding - was central to his prophetic mission and ultimate success. She applies the hermeneutic of reading the divine text as a structural unity, a concept termed al-wahda al-binā'iyya li-l-Qur'ān.

Given that the Qur'an's message is eternal and directed toward everyone, regardless of time, place, gender, and any other man-made classification or hierarchy, it was never meant to be restricted to its original audience. In contemporary terms, this concept of murabbi reflects the ability of all people to help each other advance to a higher level of morality via the strength of their commitment and personality, to inspire one another to change their expectations, perceptions, and motivations so that they can work toward common goals. In short, Alwani contends, we should leverage the method of al-wahda al-binā'iyya li-l-Qur'ān to actualize and present the term murabbi by using the Prophet's (peace be upon him) mission as a roadmap for spawning a contemporary social revolution driven by accountability, mercy, and compassion.

As she states:

The Prophet (peace be upon him) embodied and cultivated compassion and mercy through his words and his actions (21: $\underline{107})$. The Sunna represents the 
ethics, morals, and behaviors outlined in the Shari'a. The Qur'anic notion of murabbi reflects a holistic relationship among the Qur'an, the Sunna (the prophetic example), and the hadith (the prophetic tradition). As murabbiss, the onus is on us to transform and purify ourselves, which will, in turn, transform our society. As the Qur'an states: "God will not change what is in a people until they change what is in themselves. (13:11)

The purpose of this issue, and of this journal as a whole, is to raise questions that our community needs to think about and formulate realistic answers to so that we can actually begin to bring out lives closer to the roadmap laid out by the Prophet (peace be upon him). Please contribute to our discussion by sending us your feedback. Thank you!

Zainab Alwani

Editor, Journal on Islamic Faith and Practice 